\title{
Cattle movement network, herd size, and bovine brucellosis in the State of Mato Grosso, Brazil
}

\section{Rede de trânsito animal, tamanho de rebanho e brucelose bovina no Estado de Mato Grosso, Brasil}

\author{
Rafael Ishibashi Cipullo; J José Henrique Hildebrand Grisi-Filho², \\ Ricardo Augusto Dias ${ }^{2}$; Fernando Ferreira²; José Soares Ferreira Neto²; \\ Vitor Salvador Picão Gonçalves ${ }^{3}$; Fernando Silveira Marques'; \\ Rísia Lopes Negreiros'; Raul Ossada ${ }^{1} ;$ Marcos $\mathrm{Amaku}^{2 *}$
}

\begin{abstract}
The aims of the present study were to compare centrality and other measures of bovine movement networks in the state of Mato Grosso, Brazil, in 2007, by examination of the positive and negative herds identified in the brucellosis survey conducted in 2003. In addition, we aimed to examine the association between herd size (measured by the number of females older than 24 months, denoted FEM24+) and animal trade between herds. We found a statistical association between brucellosis occurrence and both the total degree (number of traded animals) and out-degree (for the number of animals sold and the number of neighboring herds). This finding suggests that positive herds in the 2003 survey were trading (particularly selling) more frequently in 2007 than negative herds, thereby presumably increasing the risk of disease spread. Statistical differences observed (p-values) in the network of movements for reproduction purposes were more significant than those observed in other networks for average herd size; degrees of animals, batches, and neighbors; outdegree of neighbors; and betweenness. We found positive associations ( $\mathrm{p}<$ 0.001 ) between the following variables: number of traded animals and the FEM24+ herd size; FEM24+ herd size and FEM24+ herd size of neighbors within the network of cattle movement; FEM24+ herd size of neighbors and number of traded animals; and weighted degree (animals) of neighbors and degree (animals) of the herd of origin. A comparison of positive and negative herds stratified by herd size ( $\leq$ 10 FEM24+; 11-50 FEM24+; and > 50 FEM24+), within the network of movements for reproduction purposes, revealed significant differences $(\mathrm{p}<0.05)$ in the $>50$ FEM24+ category only, for average herd size, total degree (animals, batches, and neighbors), outdegree (animals, batches, and neighbors), and outcloseness. Logistic regression analysis, in which average herd size and degree (animals) were both factors, showed that a tenfold increase in herd size and the number of animals traded would lead to an increased chance of a herd being positive by $41 \%(\mathrm{OR}=1.41[1.01 ; 1.99])$ and $39 \%(\mathrm{OR}=1.39[1.05$; $1.85])$, respectively. We concluded that the presence of bovine brucellosis is associated with a larger herd size, which is consistent with other reports. We also found an association between the increased trade of bovines and the presence of bovine brucellosis. Furthermore, an association was noted between herd size and animal trade, both of which could contribute to the spread of brucellosis.
\end{abstract}

Key words: Animal movement. Bovine brucellosis. Complex network. Herd size. Mato Grosso.

\footnotetext{
${ }^{1}$ Discentes, Programa de Pós-Graduação em Epidemiologia Experimental Aplicada às Zoonoses, Faculdade de Medicina Veterinária e Zootecnia, Universidade de São Paulo, USP, São Paulo, SP, Brasil. E-mail: rafael.cipullo@gmail.com; fernandosix@gmail. com; raulossada@gmail.com

2 Profs., Faculdade de Medicina Veterinária e Zootecnia, USP, São Paulo, SP, Brasil. E-mail: grisi@vps.fmvZ.usp.br; dias@vps. fmvz.usp.br; fernando@vps.fmvz.usp.br; jsoares@vps.fmvz.usp.br; amaku@vps.fmvz.usp.br

${ }^{3}$ Prof., Faculdade de Agronomia e Medicina Veterinária, Universidade de Brasília, UNB, Brasília, Brasil. E-mail: vitorspg@unb.br

${ }^{4}$ Pesquisadora, Instituto de Defesa Agropecuária do Estado do Mato Grosso, INDEA, Cuiabá, MT, Brasil. E-mail: risianegreiros@ yahoo.com.br

* Author for correspondence
} 


\section{Resumo}

O objetivo do presente estudo foi comparar medidas de centralidade e outras medidas da rede de trânsito bovino no estado de Mato Grosso, Brasil, em 2007, pela análise de rebanhos positivos e negativos identificados no levantamento de brucelose realizado em 2003. Além disso, examinamos a associação entre tamanho de rebanho (medido pelo número de fêmeas acima de 24 meses, denotado FEM24+) e o comércio animal entre rebanhos. Foi observada uma associação estatística entre brucelose e tanto o grau total (número de animais comercializados) quanto o grau de saída (para número de animais vendidos e número de rebanhos vizinhos). Tal associação sugere que rebanhos positivos no levantamento de 2003 comercializavam (em particular, vendiam) com mais frequência em 2007 que rebanhos negativos, aumentando presumivelmente o risco de espalhamento da doença. Diferenças estatísticas observadas (valore de $\mathrm{p}$ ) na rede de trânsito para reprodução foram mais significativas do que aqueles observadas em outras redes para tamanho médio de rebanho; grau de animais, lotes e vizinhos; grau de saída de vizinhos; e centralidade por intermediação ("betweenness"). Observamos associações. Encontramos associações positivas $(\mathrm{p}<0,001)$ entre as seguintes variáveis: número de animais comercializados e FEM24+; FEM24+ e FEM24+ de vizinhos na rede de trânsito bovino; FEM24+ de vizinhos e número de animais comercializados; e grau ponderado (animais) de vizinhos e grau (animais) do rebanho de origem. Uma comparação entre rebanhos positivos e negativos estratificados por tamanho de rebanho ( $\leq$ 10 FEM24 +; 11-50 FEM24+; e > 50 FEM24+), na rede de trânsito para reprodução, revelou diferenças significativas $(\mathrm{p}<0,05)$ somente na categoria $>50$ FEM24+, para tamanho médio de rebanho, grau total (animais, lotes e vizinhos), grau de saída (animais, lotes e vizinhos), e centralidade por proximidade ("closeness") de saída. Uma análise de regressão logística, em que tamanho médio de rebanho e grau (animais) foram os fatores, mostrou que um aumento de 10 vezes no tamanho do rebanho e no número de animais comercializados levaria a um aumento na chance de um rebanho ser positivo de $41 \%$ (OR $=1,41[1,01 ; 1,99])$ e $39 \%(\mathrm{OR}=1,39[1,05 ; 1,85])$, respectivamente. Concluímos que a presença de brucelose bovina está associada com tamanho de rebanho maior, o que é consistente com outros relatos. Encontramos uma associação entre o aumento de comércio de bovinos e a presença de brucelose bovina. Além disso, foi observada uma associação entre o tamanho de rebanho e o comércio animal, ambos dos quais poderiam contribuir para o espalhamento de brucelose.

Palavras-chave: Brucelose bovina. Rede complexa. Tamanho de rebanho. Trânsito animal. Mato Grosso.

\section{Introduction}

The association between herd size and the presence of bovine brucellosis has been reported in previous studies (MATOPE et al., 2010; SALMAN; MEYER, 1984). In particular, herd size has been identified as a risk factor for bovine brucellosis in epidemiological surveys conducted in some Brazilian states (CHATE et al., 2009; DIAS et al., 2009b; KLEIN-GUNNEWIEK et al., 2009; NEGREIROS et al., 2009; OGATA et al., 2009; SILVA et al., 2009) and in the nationwide analysis of Brazil (MOTA et al., 2016).

Some features of large herds, such as a higher frequency of animal replacement, could influence the transmission dynamics of bovine brucellosis. Thus, cattle herd size and animal trade are potentially associated factors that might interact and thereby affect the dynamics of bovine brucellosis.
To analyze the network of animal movements among farm premises, we applied methods of social network analysis. These methods have been long established in the fields of sociology, psychology, anthropology, and biology (MARTÍNEZ-LÓPEZ et al., 2009); however, their application in the field of veterinary medicine has been relatively recent. The first of such studies were conducted by Bigras-Poulin et al. (2006), Christley et al. (2003), Corner et al. (2003), and Webb and Sauter-Louis (2002). The network analysis currently applied to veterinary epidemiology goes beyond a simple description of the pattern of animal movements and is applied: to the mathematical modelling of the spread of disease within a network (BAJARDI et al., 2012); to provide support for risk analysis and risk-based sampling based on the detection of livestock production zones (GRISI-FILHO et al., 
2013; LENTZ et al., 2011); and to the surveillance and control of infectious diseases (AMAKU et al., 2015; SCHÄRRER et al., 2015).

In animal movement networks, farm premises are considered the nodes and animal movements are the edges connecting these nodes. The networks of animal movements, particularly cattle movements, have specific characteristics: they are directed, dynamic, and have a high degree of heterogeneity (BIGRAS-POULIN et al., 2006). In addition, the degree distribution of some of these networks follows a power law (BIGRAS-POULIN et al., 2006; NEGREIROS, 2010). Therefore, in the analysis of networks of animal movements, one must be careful to consider these characteristics.

The aims of the present study were twofold: first, to compare positive and negative herds identified in the brucellosis survey conducted in 2003, regarding the centrality measures in the network of bovine movements in the state of Mato Grosso, Brazil, in 2007; and second, to examine the association between herd size (particularly females older than 24 months, denoted FEM24+) and animal trade.

\section{Materials and Methods}

\section{Database}

The state of Mato Grosso (MT) had the largest cattle herd (25.7 million cattle) in Brazil in 2007 (IBGE, 2015). Since the herd size of a given premises could vary during the year, we calculated the mean between the herd size on December 31, 2006 and on December 31,2007, to estimate the average herd size of the farm premises of Mato Grosso.

To calculate the network centrality measures, we used the cattle movement network of the state of Mato Grosso in 2007. Both databases (herd size and cattle movement network) were provided by the local veterinary agency (Instituto de Defesa Agropecuária do Estado de Mato Grosso, INDEAMT).

The herd status (positive or negative for brucellosis) was obtained from the database of the 2003 bovine brucellosis survey of the National Program for Control and Eradication of Animal Brucellosis and Tuberculosis (Programa Nacional de Controle e Erradicação da Brucelose e da Tuberculose Animal - PNCEBT).

Figure 1. Livestock movement network of positive (red nodes), negative (green nodes), and unknown status premises (white nodes) in the state of Mato Grosso in 2007.

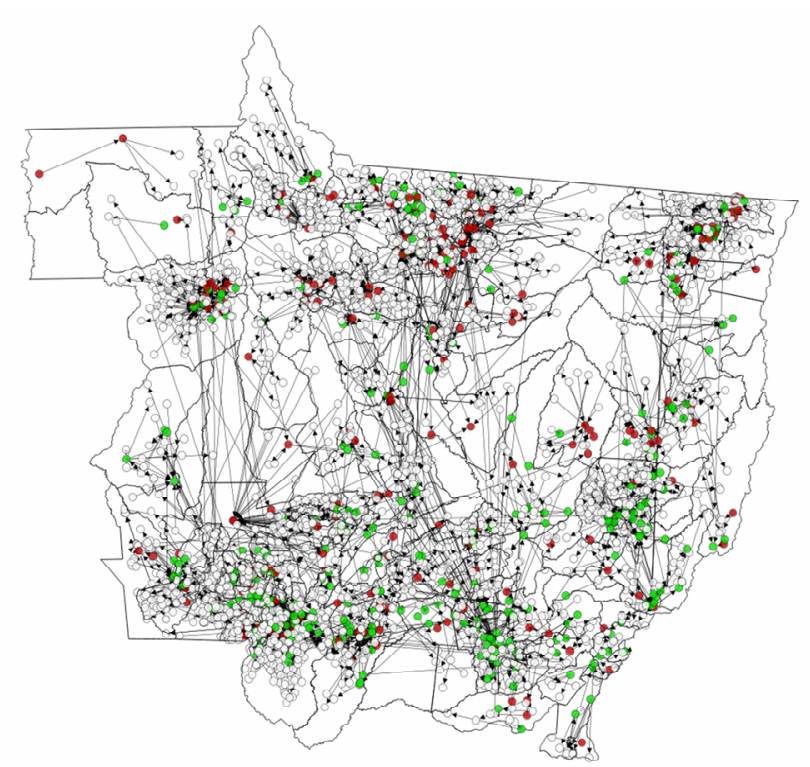


In an epidemiological survey carried out in the state of Mato Grosso in 2003, 1,115 herds were sampled and a prevalence on herd level of $41.2 \%$ of bovine brucellosis was estimated (NEGREIROS et al., 2009). Of these 1,115 herds, 641 (262 positive and 379 negative) were in the animal movement network of MT. We gathered information about the trade of cattle among these herds in 2007 (Figure 1).

\section{Network centrality measures}

We calculated the following network measures (NEWMAN, 2010): degree (total, incoming and outgoing); betweenness; closeness; clustering coefficient; PageRank; and ingoing and outgoing contact chain (NöREMARK; WIDGREN, 2014). A more detailed description of these network measures is presented in the Appendix. Each of these measures is used to shed light on a different aspect of the network analysis. In summary, the aforementioned centrality measures could be described from a practical point of view as follows:

1. The degree is the simplest centrality measure and indicates how connected a given premises is within the network. It can be calculated in three different forms: the degree of neighbors indicates the number of trade neighbors (within the network of animal movements, not necessarily a spatially close neighbor) of a given farm premises; the degree of animals and batches indicate how many animals or batches of animals, respectively, that the reference farm premises moved within the network. The degree may be calculated considering only animals or batches purchased (indegree) or sold (outdegree).

2. The betweenness of a given premises indicates its importance as a "bridge" between two other premises, or two distinct groups of premises. Premises with high betweenness have considerable influence on the flow control of an animal movement network, and their removal for instance, through quarantine during an outbreak, can lead to fragmentation of the network, thereby making other premises less reachable.

3. The closeness of premises indicates how close other premises are to a given premises, in terms of network distance.

4. The clustering coefficient of premises evaluates the fraction of pairs of neighboring farm premises (of the reference premises) that are also neighbors of each other in terms of trade.

5. The PageRank indicates the importance of the premises with regard to the number and origin of animals bought. The PageRank calculation takes into account the indegree of a given premises and the indegree of its neighbors.

6. The ingoing and outgoing contact chain (ICC and OCC, respectively) refer to the number of premises in direct and indirect contact with a given farm premises, considering movements that have the reference premises as either a target or a source node, respectively, and taking into account the temporal coherence. The contact chain indicates possible routes for the movement of an animal within the network or even for the potential spread of an infection.

These network measures were calculated for positive and negative herds using the $\mathrm{R}$ software ( $\mathrm{R}$ CORE TEAM, 2015) and igraph package (CSARDI; NEPUSZ, 2006), considering the following networks: all bovine movements ("whole network"); movements for fattening purposes only ("fattening only"); movements for reproduction purposes only ("reproduction only"); and a final network in which the movements to slaughterhouses were disregarded ("without abattoirs"). To investigate the influence of herd size further, analysis was carried out for the network of movements for reproduction purposes, with stratification by herd size, using the same categories as those of the brucellosis survey in the State of Mato Grosso (NEGREIROS et al., 2009), specifically: $\leq 10$ females older than 24 months (FEM24+); 11-50 FEM24+; and > 50 FEM24+ in the herd. 
Comparisons between the network measures of positive and negative herds were performed using the nonparametric Mann-Whitney test with a significance level of $\alpha=0.05$.

\section{Analysis of the association between cattle movement network and herd size}

The following comparisons, regarding herd size and the number of traded animals, both in 2007 , were carried out between:

1. the number of FEM24+ and the number of animals traded by each herd;

2. the number of FEM24+ of a given herd and the mean FEM24+ of its neighbors, weighted by the number of traded (sold and bought) animals (degree);

3. the number of animals traded by a herd and the mean FEM24+ of its neighboring herds, weighted by the number of traded animals; and

4. the number of animals traded by a herd and the average degree (animals) of neighbors, weighted by the number of traded animals.
We chose the age interval FEM24+ because this interval was also used in the bovine brucellosis surveys conducted in Brazil (CHATE et al., 2009; DIAS et al., 2009b; KLEIN-GUNNEWIEK et al., 2009; NEGREIROS et al., 2009; OGATA et al., 2009; SILVA et al., 2009).

To draw these comparisons and display the data graphically using boxplots, we partitioned the values of FEM24+ size and the degree of animals in deciles (i.e., we divided the data distribution into 10 quantiles). The statistical comparisons among deciles were carried out using the nonparametric Kruskal-Wallis statistical test with a significance level of $\alpha=0.05$.

\section{Results and Discussion}

The number of farm premises, edges (equivalent to bovine movements), batches of animals, and animals moved are presented in Table 1, for the networks analyzed; the networks with movements to slaughterhouses only ("slaughter only"); and networks with movements for other purposes ("other purposes"), such as exhibition, markets, sports, and work.

Table 1. Number of nodes (farm premises), edges (animal movements connecting the nodes), batches of animals, and number of animals moved for the various networks analyzed.

\begin{tabular}{lrrrrrrrr}
\hline Network & \multicolumn{2}{c}{ \# of nodes } & \multicolumn{2}{c}{ Edges } & \multicolumn{2}{c}{ Batches } & \multicolumn{2}{c}{ Animals moved } \\
\hline Whole network & 88,451 & $100 \%$ & 202,235 & $100 \%$ & 536,213 & $100 \%$ & $15,965,825$ & $100 \%$ \\
Slaughter only & 22,241 & $25 \%$ & 35,027 & $17 \%$ & 254,669 & $47 \%$ & $5,031,387$ & $32 \%$ \\
Without abattoirs & 86,343 & $98 \%$ & 167,208 & $83 \%$ & 281,544 & $53 \%$ & $10,934,438$ & $68 \%$ \\
Fattening only & 64,968 & $73 \%$ & 105,212 & $52 \%$ & 178,664 & $33 \%$ & $6,944,103$ & $43 \%$ \\
Reproduction only & 49,635 & $56 \%$ & 61,199 & $30 \%$ & 90,609 & $17 \%$ & $3,623,514$ & $23 \%$ \\
Other purposes & 3,641 & $4 \%$ & 5,989 & $3 \%$ & 12,271 & $2 \%$ & 366,821 & $2 \%$ \\
\hline
\end{tabular}

Tables 2 and 3 show the results of the comparisons between positive and negative herds for different network measures and the average number of bovines, considering the following networks: all bovine movements; movements for fattening purposes; movements for reproduction purposes; and the network excluding movements to slaughterhouses. Statistically significant differences $(p<0.05)$ between positive and negative herds were observed for the following variables: 
Table 2. Estimates of medians and interquartile ranges (IQR) for several parameters of the various networks analyzed. The p-values are derived from the Mann-Whitney tests comparing negative $(\mathrm{N})$ and positive $(\mathrm{P})$ herds. Significant differences $(\mathrm{p}<0.05)$ are highlighted in bold.

\begin{tabular}{|c|c|c|c|c|c|c|c|c|c|c|c|c|c|}
\hline \multirow{4}{*}{$\begin{array}{l}\text { Parameter } \\
\text { average herd size }\end{array}$} & \multirow{4}{*}{$\begin{array}{l}\text { Status } \\
\mathrm{N} \\
\mathrm{P}\end{array}$} & \multicolumn{3}{|c|}{ Whole network } & \multicolumn{3}{|c|}{ Without abattoirs } & \multicolumn{3}{|c|}{ Fattening only } & \multicolumn{3}{|c|}{ Reproduction only } \\
\hline & & \multicolumn{2}{|c|}{$\begin{array}{c}\text { Median } \\
\text { (IQR) }\end{array}$} & \multirow{3}{*}{$\begin{array}{c}\text { p-value } \\
0.047\end{array}$} & \multicolumn{2}{|c|}{$\begin{array}{c}\text { Median } \\
\text { (IQR) }\end{array}$} & \multirow{3}{*}{$\begin{array}{c}\text { p-value } \\
0.039\end{array}$} & \multicolumn{2}{|c|}{$\begin{array}{c}\text { Median } \\
\text { (IQR) }\end{array}$} & \multirow{3}{*}{$\begin{array}{c}\text { p-value } \\
0.067\end{array}$} & \multicolumn{2}{|c|}{$\begin{array}{c}\text { Median } \\
\text { (IQR) }\end{array}$} & \multirow{3}{*}{$\begin{array}{r}\text { p-value } \\
0.001\end{array}$} \\
\hline & & 125 & (208) & & 123 & (205) & & 127 & (234) & & 114 & (178) & \\
\hline & & 164 & (376) & & 164 & (377) & & 176 & (372) & & 208 & (495) & \\
\hline \multirow{2}{*}{$\mathrm{k}^{\text {in }}$ (animals) } & $\mathrm{N}$ & 0.0 & $(53)$ & \multirow{2}{*}{0.323} & 1 & $(56)$ & \multirow{2}{*}{0.322} & 0 & $(38)$ & \multirow{2}{*}{0.711} & 2 & $(40)$ & \multirow{2}{*}{0.129} \\
\hline & $\mathrm{P}$ & 2.5 & (73) & & 4 & (77) & & 0 & (43) & & 7 & $(65)$ & \\
\hline \multirow{2}{*}{$\mathrm{k}^{\text {out }}$ (animals) } & $\mathrm{N}$ & 53.0 & (156) & \multirow{2}{*}{0.001} & 35 & (116) & \multirow{2}{*}{$<0.001$} & 29 & (96) & \multirow{2}{*}{0.010} & 19 & $(62)$ & \multirow{2}{*}{$<0.001$} \\
\hline & $\mathrm{P}$ & 89.5 & (325) & & 64 & (206) & & 46 & (142) & & 36 & (142) & \\
\hline \multirow{2}{*}{ k (animals) } & $\mathrm{N}$ & 80 & (236) & \multirow{2}{*}{0.006} & 60 & (167) & \multirow{2}{*}{0.003} & 48.5 & (150) & \multirow{2}{*}{0.051} & 39 & (117) & \multirow{2}{*}{0.001} \\
\hline & $\mathrm{P}$ & 114 & (399) & & 83 & (321) & & 69.5 & (246) & & 63 & (220) & \\
\hline \multirow{2}{*}{$\mathrm{k}^{\text {in }}$ (batches) } & $\mathrm{N}$ & 0 & (2) & \multirow{2}{*}{0.458} & 1 & (2) & 0.461 & 0 & (2) & 0758 & 1 & (2) & 0115 \\
\hline & $\mathrm{P}$ & 1 & (2) & & 1 & (3) & 0.401 & 0 & (2) & 0.158 & 1 & (3) & 0.115 \\
\hline (batches) & $\mathrm{N}$ & 3 & (6) & $0.015>>5$ & 2 & (3) & $0.00+>>0$ & 2 & (2) & $0.02+3$ & 1 & (1) & 4 \\
\hline & $\mathrm{P}$ & 4 & (9) & 0.015 & 3 & (5) & 0.00 & 2 & (4) & 0.020 & 1 & (2) & \\
\hline k (hatches) & $\mathrm{N}$ & 4 & (8) & 0063 & 3 & (5) & $0.017>>$ & 3 & (4) & 0085 & 2 & (3) & 0006 \\
\hline K (Uatciles) & $\mathrm{P}$ & 5 & (13) & 0.005 & 4 & (7) & 0.011 & 3 & (6) & $0.00 \mathrm{~J}$ & 2 & (5) & 0.000 \\
\hline $\mathrm{k}^{\text {in }}$ (neighbors) & $\mathrm{N}$ & 0 & (2) & 0.628 & 1 & (2) & 0.637 & 0 & (1) & 0.810 & 1 & (1) & $0.131 \mathrm{H}-\mathrm{g}$ \\
\hline & $\mathrm{P}$ & 1 & (2) & 0.628 & 1 & (2) & 0.031 & 0 & (1) & 0.810 & 1 & (2) & 0.131 \\
\hline $\mathrm{k}^{\text {out }}$ (neighbors) & $\mathrm{N}$ & 2 & (3) & 0.033 & 2 & (2) & 0.007 & 1 & (2) & 0061 & 1 & (1) & 0.004 \\
\hline K (III)IgIVOIS) & $\mathrm{P}$ & 2 & (4) & 0.035 & 2 & (3) & 0.001 & 2 & (2) & 0.001 & 1 & (1) & 0.004 \\
\hline k (neighbors) & $\mathrm{N}$ & 3 & (4) & 0.139 & 2 & (4) & 0.063 & 2 & (2) & 0.212 & 1 & (2) & 0.008 \\
\hline K (neighbors) & $\mathrm{P}$ & 3 & (5) & 0.139 & 3 & (4) & 0.063 & 2 & (3) & 0.212 & 2 & (2) & 0.008 \\
\hline
\end{tabular}

$\mathrm{k}$, degree; $\mathrm{k}^{\text {in }}$, indegree; $\mathrm{k}^{\text {out }}$, outdegree. 
Table 3. Estimates of medians and interquartile ranges (IQR) for several parameters of the various networks analyzed. The $\mathrm{p}$-values are derived from the Mann-Whitney tests comparing negative $(\mathrm{N})$ and positive $(\mathrm{P})$ herds. Significant differences $(\mathrm{p}<0.05)$ are highlighted in bold.

\begin{tabular}{|c|c|c|c|c|c|c|c|c|c|c|c|c|c|}
\hline \multirow{4}{*}{$\begin{array}{l}\text { Parameter } \\
\text { betweenness }\end{array}$} & \multirow{4}{*}{$\begin{array}{l}\text { Status } \\
\mathrm{N} \\
\mathrm{P}\end{array}$} & \multicolumn{3}{|c|}{ Whole network } & \multicolumn{3}{|c|}{ Without abattoirs } & \multicolumn{3}{|c|}{ Fattening only } & \multicolumn{3}{|c|}{ Reproduction only } \\
\hline & & \multicolumn{2}{|c|}{ Median (IQR) } & \multirow{3}{*}{$\begin{array}{c}\text { p-value } \\
0.308\end{array}$} & \multicolumn{2}{|c|}{ Median (IQR) } & \multirow{3}{*}{$\begin{array}{c}\text { p-value } \\
0.102\end{array}$} & \multicolumn{2}{|c|}{ Median (IQR) } & \multirow{3}{*}{$\begin{array}{c}\text { p-value } \\
0.393\end{array}$} & \multicolumn{2}{|c|}{ Median (IQR) } & \multirow{3}{*}{$\begin{array}{r}\text { p-value } \\
0.006\end{array}$} \\
\hline & & 0 & (5720) & & 0 & $(953$ & & 0 & (3) & & 0 & (1) & \\
\hline & & 0 & (21000) & & 0 & $(22800)$ & & 0 & (25) & & 0 & (33) & \\
\hline \multirow{2}{*}{ closeness in } & $\mathrm{N}$ & $1 \mathrm{e}-10$ & $(3 e-14)$ & \multirow{2}{*}{0.759} & $1 \mathrm{e}-10$ & $(2 \mathrm{e}-10)$ & \multirow{2}{*}{0.772} & $2 \mathrm{e}-10$ & $(1 \mathrm{e}-14)$ & \multirow{2}{*}{0.921} & $4 e-10$ & $(3 e-14)$ & \multirow{2}{*}{0.206} \\
\hline & $\mathrm{P}$ & $1 \mathrm{e}-10$ & $(2 \mathrm{e}-10)$ & & $1 \mathrm{e}-10$ & $(2 \mathrm{e}-10)$ & & $2 \mathrm{e}-10$ & $(7 e-15)$ & & $4 \mathrm{e}-10$ & $(3 e-14)$ & \\
\hline \multirow{2}{*}{ closeness out } & $\mathrm{N}$ & $2 \mathrm{e}-10$ & $(5 \mathrm{e}-11)$ & \multirow{2}{*}{0.992} & $2 \mathrm{e}-10$ & $(5 e-11)$ & \multirow{2}{*}{0.980} & $3 e-10$ & $(4 \mathrm{e}-11)$ & \multirow{2}{*}{0.461} & $4 e-10$ & $(6 e-11)$ & \multirow{2}{*}{0.192} \\
\hline & $\mathrm{P}$ & $2 \mathrm{e}-10$ & $(5 \mathrm{e}-11)$ & & $2 \mathrm{e}-10$ & $(5 e-11)$ & & $3 e-10$ & $(4 \mathrm{e}-11)$ & & $4 e-10$ & 1) & \\
\hline \multirow{2}{*}{ clustering in } & $\mathrm{N}$ & 0 & $(0.012)$ & \multirow{2}{*}{0.656} & 0 & $(0.012)$ & \multirow{2}{*}{0.656} & 0 & (0) & \multirow{2}{*}{0.288} & 0 & (0) & \multirow{2}{*}{0.187} \\
\hline & $\mathrm{P}$ & 0 & $(0.014)$ & & 0 & $(0.014)$ & & 0 & (0) & & 0 & (0) & \\
\hline \multirow{2}{*}{ clustering out } & $\mathrm{N}$ & 0 & $(0.08)$ & \multirow{2}{*}{0.134} & 0 & $(0.007)$ & \multirow{2}{*}{0.053} & 0 & (0) & \multirow{2}{*}{0.050} & 0 & (0) & 0948 \\
\hline & $\mathrm{P}$ & 0 & $(0.10)$ & & 0 & $(0.048)$ & & 0 & (0) & & 0 & (0) & \\
\hline & $\mathrm{N}$ & $5 e-06$ & $(4 \mathrm{e}-06)$ & & $4 \mathrm{e}-06$ & $(4 \mathrm{e}-06)$ & 06 & $6 e-06$ & $(5 e-06)$ & & $9 e-06$ & $(8 e-06)$ & 32 \\
\hline Ra & $\mathrm{P}$ & $5 e-06$ & $(4 \mathrm{e}-06)$ & $0.5 / 2$ & $4 e-06$ & $(4 e-06)$ & $0.6 / 0$ & $6 e-06$ & $(5 \mathrm{e}-06)$ & 900 & $9 e-06$ & $(9 \mathrm{e}-06)$ & 0.332 \\
\hline ICC & $\mathrm{N}$ & 0 & (4) & 0688 & 1 & (4) & 0699 & 0 & (2) & 09 & 1 & (2) & 0202 \\
\hline & $\mathrm{P}$ & 1 & (4) & 0.000 & 1 & (5) & & 0 & (2) & 0.740 & 1 & (2) & \\
\hline & $\mathrm{N}$ & 10 & (72) & 0156 & 8 & (65) & 0,0 & 4 & (16) & 322 & 1 & (4) & 0058 \\
\hline & $\mathrm{P}$ & 17 & (82) & 0.150 & 13 & (75) & & 5 & (20) & & 2 & (5) & \\
\hline
\end{tabular}

ICC, ingoing contact chain; OCC, outgoing contact chain.

1. in the whole network: average number of animals in the farm; total degree (for the number of animals moved); and outdegree (for animals, batches of animals, and neighboring premises).

2. in the network disregarding movements to slaughterhouses ("without abattoirs"): average number of animals on the farm; total degree (for animals and batches of animals moved); and outdegree (for animals, batches of animals, and neighboring herds).

3. in the network for fattening purposes ("fattening only"): outdegree (for animals and batches of animals moved).

4. in the network for reproduction purposes ("reproduction only"): mean number of animals on the farm; total degree (for animals, batches of animals, and neighboring herds); outdegree (for animals, batches of animals, and neighboring herds); and betweenness.
Regarding the association between herd size and the number of traded animals in 2007, and considering the data partitioned in deciles of the independent variable, we observed the following:

1. the median number of traded animals increased as the FEM24+ herd size increased (Figure 2). A similar pattern was observed in the analysis of the number of animals bought or sold as a function of FEM24+ herd size (graphs not shown).

2. the median weighted FEM24+ herd size of the herd neighbors increased as the FEM24+ herd size increased (Figure 3).

3. the median weighted FEM24+ herd size of the herd neighbors increased as the number of animals traded increased (Figure 4).

4. the median number of animals traded by neighbors increased as the number of animals traded by a herd increased (Figure 5). 
In each of these four comparisons, we found statistically significant differences $(p<0.001)$ among the data grouped in deciles of either FEM24+ herd size or the number of traded animals.

Table 4 shows the results of comparisons between positive and negative herds in the network with movements for reproduction purposes only among three herd sizes ( $\leq 10$ FEM24+, 11-50 FEM24+, and $>50$ FEM24+). Statistically significant differences $(p<0.05)$ between positive and negative herds were observed only in the herd size category of $>50$ FEM24+ for the following variables: average herd size; total degree (for animals, batches of animals, and neighboring herds); outdegree (for animals, batches of animals, and neighboring herds); and outcloseness.

In order to determine whether herd size and the number of animals moved would be correlated or whether both would contribute to the presence of bovine brucellosis in a herd, we carried out logistic regression analysis considering the herd status (positive or negative) for bovine brucellosis as the outcome variable and base 10 logarithm of both average herd size and total degree (for animals moved) as the predictor variables. The results of the network for reproduction purposes are presented in Table 5. Both the logarithm of herd size and that of outdegree were associated with brucellosis status. A tenfold increase in herd size is predicted to lead to an increased chance of a positive status by $41 \%$ (OR $=1.41[1.01 ; 1.99])$; and a tenfold increase in the number of animals traded (purchased and sold) is predicted to lead to an increased chance of a positive herd status by $39 \%(\mathrm{OR}=1.39$ [1.05; 1.85]).

From all batches sold for reproduction purposes that originated from herds included in the brucellosis survey, $36.6 \%$ were from positive herds.

Figure 2. Boxplots of degree (number of animals bought or sold) for each decile category of herd size. Herd size is defined as the number of females of reproductive age (FEM24+).

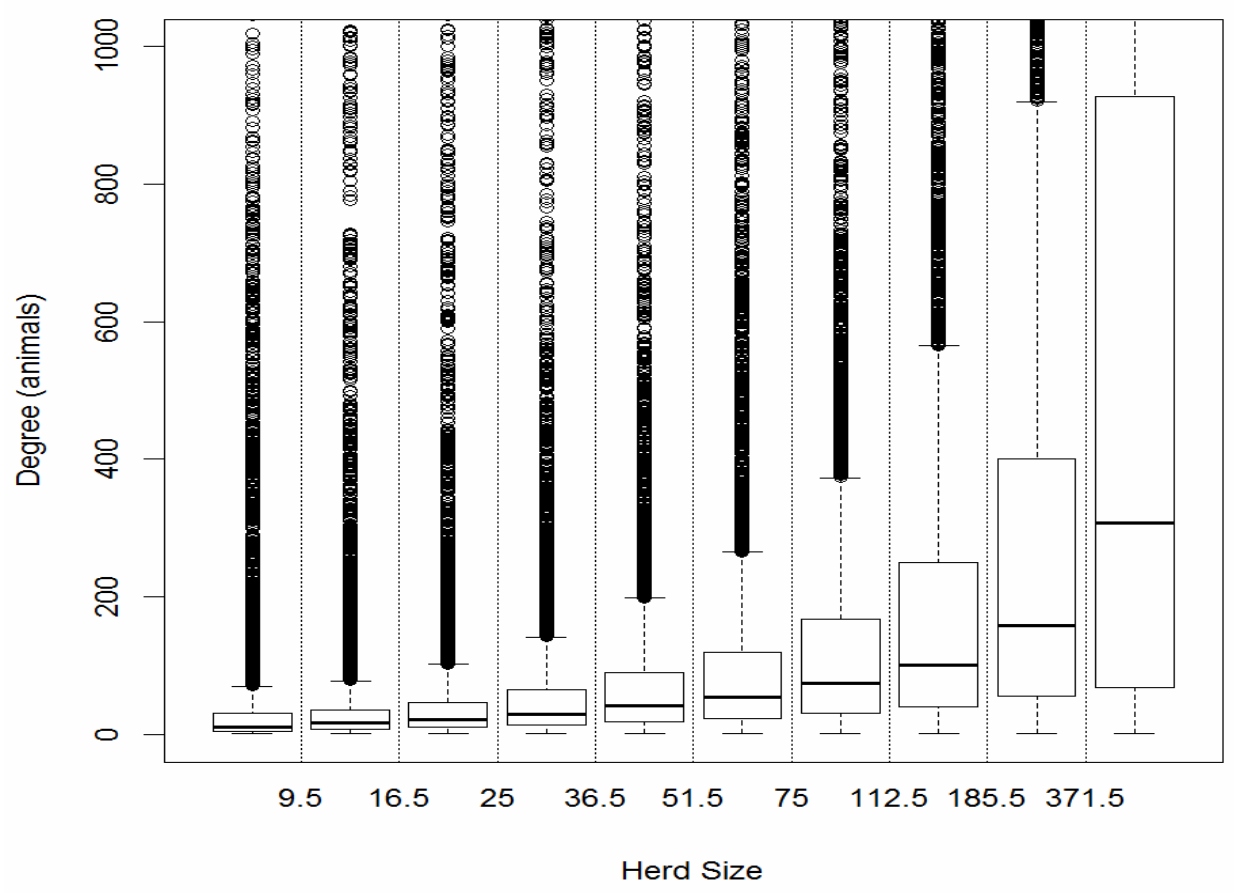


Figure 3. Boxplots of herd size of neighbors (weighted by trade intensity, i.e., the number of animals bought or sold to each neighbor) for each decile category of herd size. Herd size is defined as the number of females of reproductive age (FEM24+).

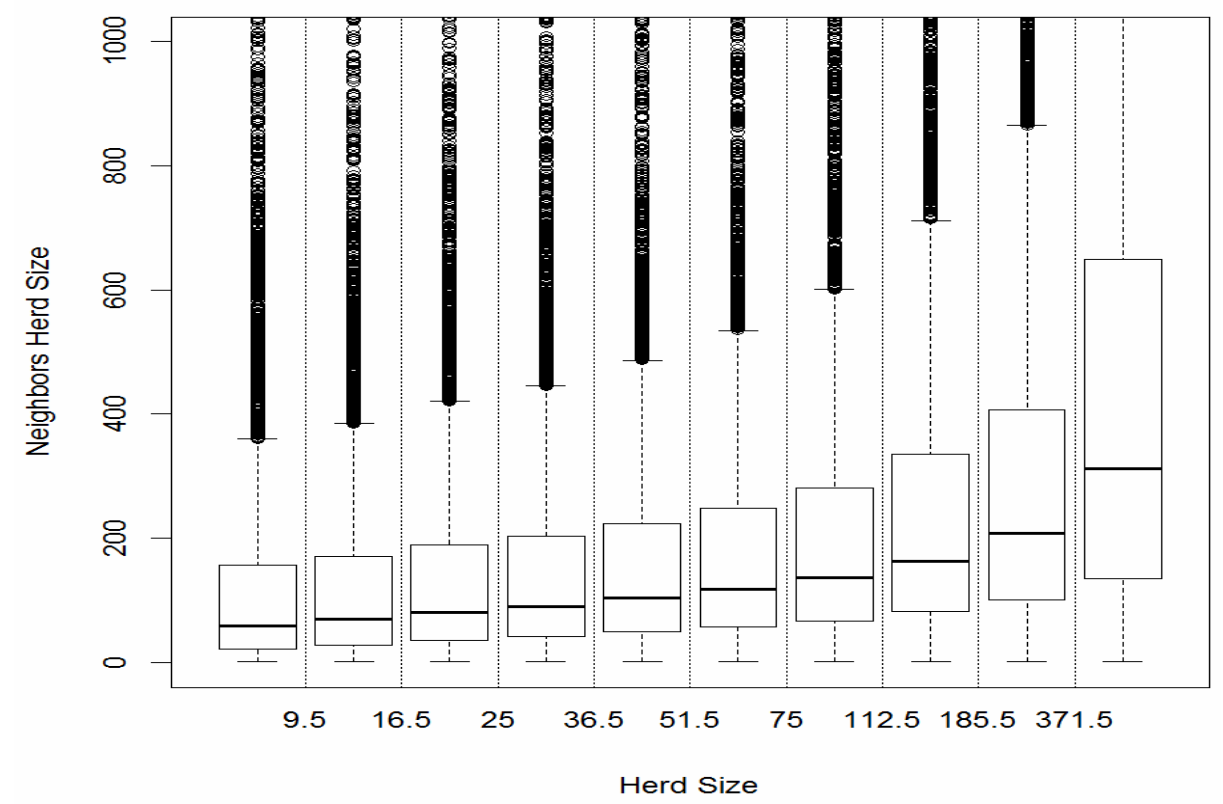

Figure 4. Boxplots of herd size of neighbors (weighted average by trade intensity, i.e., the number of animals bought or sold to each neighbor) for each decile category by degree (the number of animals bought or sold).

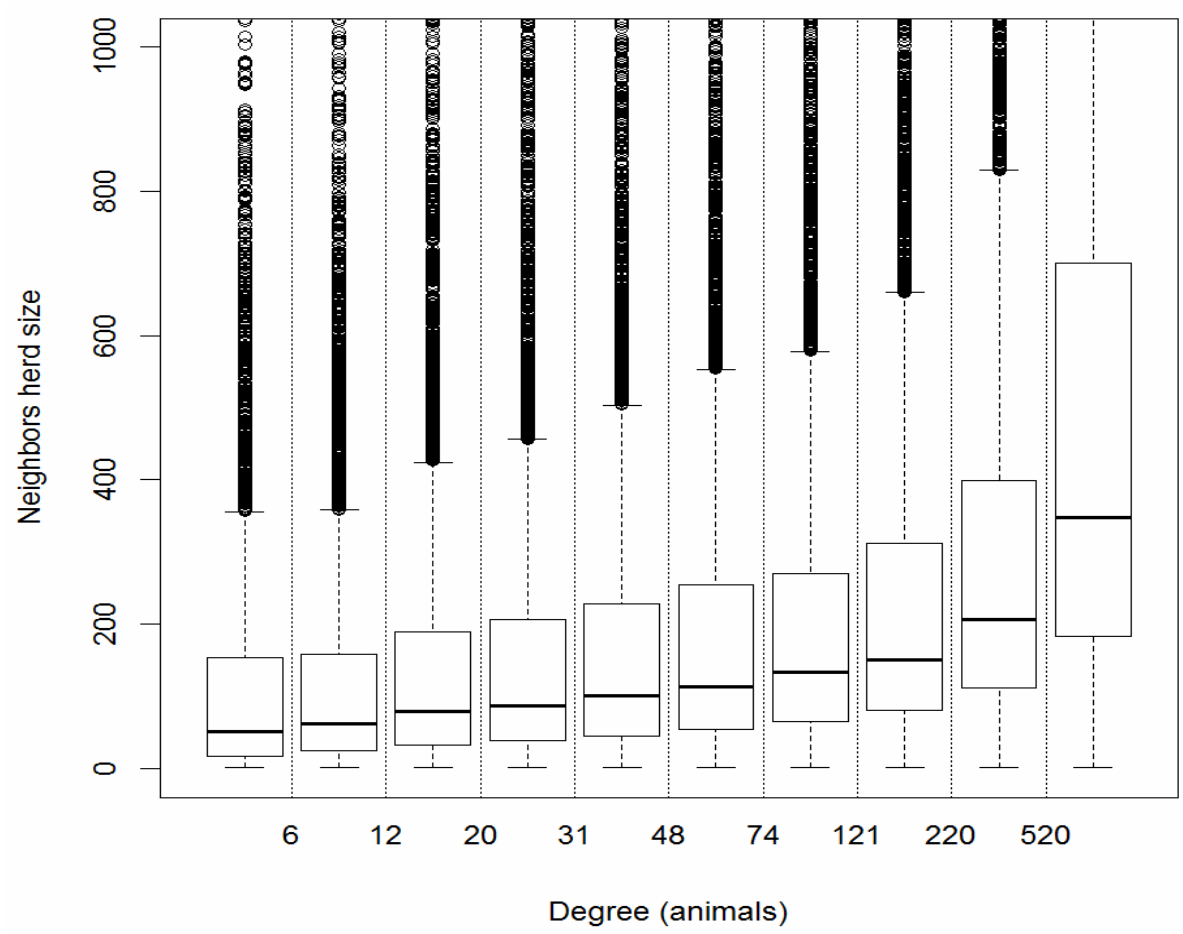


Figure 5. Boxplots of degree of neighbors (number of animals traded by a neighbor, weighted average by trade intensity, i.e., the number of animals bought or sold to each neighbor) for each decile category by degree (the number of animals bought or sold by premises).

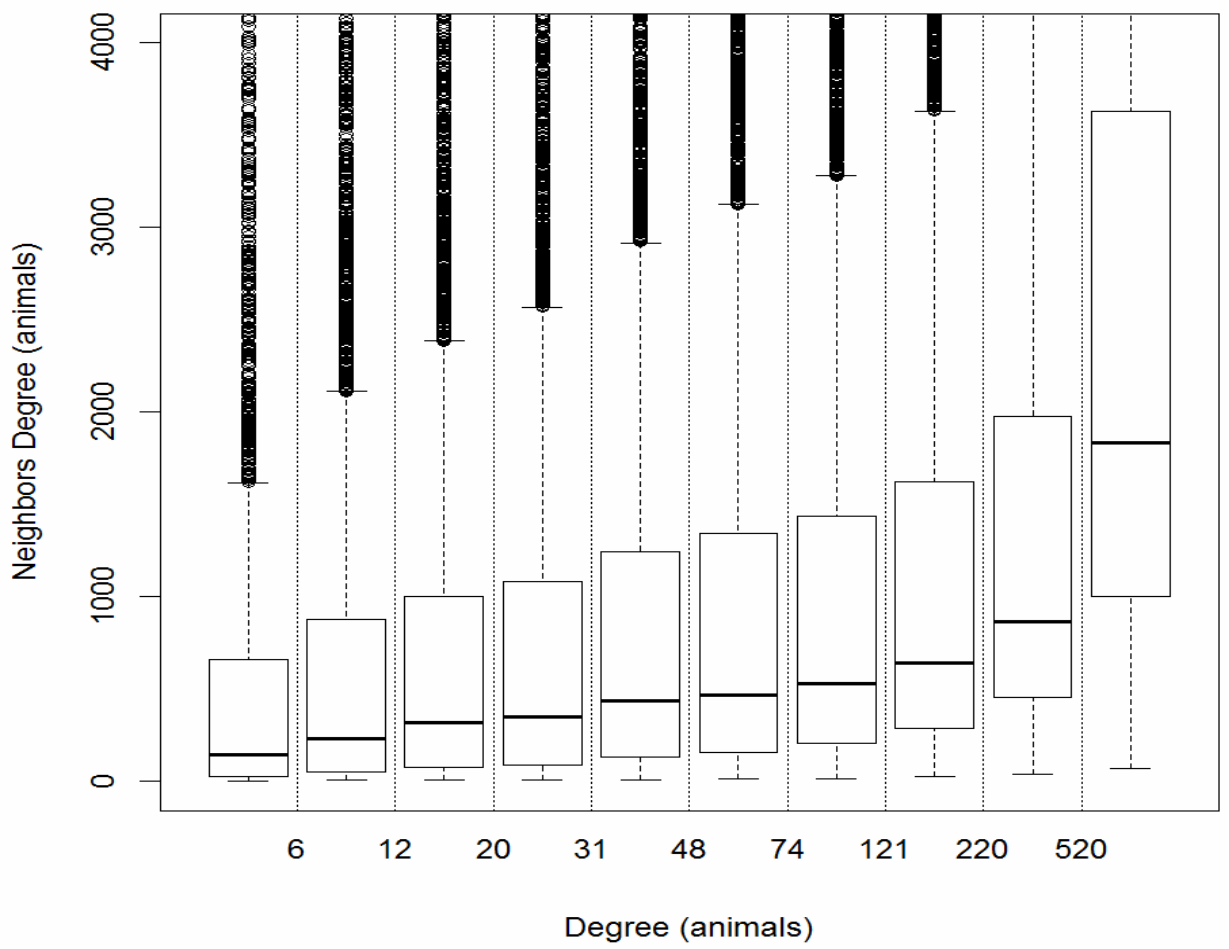

Table 4. Estimates of medians and interquartile ranges (IQR) for several parameters of the network with movements for reproduction purposes only among three herd sizes. The p-values are derived from the Mann-Whitney tests comparing negative $(\mathrm{N})$ and positive $(\mathrm{P})$ herds. Significant differences $(\mathrm{p}<0.05)$ are highlighted in bold. The numbers of positive and negative herds are indicated below the respective herd size categories.

\begin{tabular}{|c|c|c|c|c|c|c|c|c|c|c|}
\hline \multirow{3}{*}{ Parameter } & \multirow{3}{*}{ Status } & \multicolumn{2}{|c|}{$\leq 10$ females } & \multicolumn{4}{|c|}{$11-50$ females } & \multicolumn{3}{|c|}{$\geq 51$ females } \\
\hline & & \multicolumn{2}{|c|}{$\mathrm{N}=17, \mathrm{P}=12$} & \multicolumn{4}{|c|}{$\mathrm{N}=217, \mathrm{P}=135$} & \multicolumn{3}{|c|}{$\mathrm{N}=78, \mathrm{P}=30$} \\
\hline & & \multicolumn{2}{|c|}{ Median (IQR) } & p-value & \multicolumn{2}{|c|}{ Median (IQR) } & $\mathrm{p}$-value & \multicolumn{2}{|c|}{ Median (IQR) } & $\mathrm{p}$-value \\
\hline \multirow{2}{*}{ average herd size } & $\mathrm{N}$ & 7 & (4) & \multirow{2}{*}{0.361} & 29.5 & $(18.8)$ & \multirow{2}{*}{0.266} & 172 & $(230)$ & \multirow{2}{*}{$<0.001$} \\
\hline & $\mathrm{P}$ & 8 & (1.75) & & 27 & (19.6) & & 282 & $(530)$ & \\
\hline \multirow{2}{*}{ kin (animals) } & $\mathrm{N}$ & 0 & (14) & \multirow{2}{*}{0.865} & 0 & (8) & \multirow{2}{*}{0.473} & 8 & (61) & \multirow{2}{*}{0.29} \\
\hline & $\mathrm{P}$ & 1.5 & (7.25) & & 0 & $(8.75)$ & & 15 & (106) & \\
\hline \multirow{2}{*}{ kout (animals) } & $\mathrm{N}$ & 19 & $(25)$ & \multirow{2}{*}{0.639} & 10 & (19.8) & \multirow{2}{*}{0.502} & 30 & $(100)$ & \multirow{2}{*}{0.001} \\
\hline & $\mathrm{P}$ & 16.5 & $(52)$ & & 14 & (31) & & 60 & (202) & \\
\hline \multirow{2}{*}{$\mathrm{k}$ (animals) } & $\mathrm{N}$ & 21 & (15) & \multirow{2}{*}{0.626} & 15.5 & $(27.8)$ & \multirow{2}{*}{0.367} & 55 & (163) & \multirow{2}{*}{0.002} \\
\hline & $\mathrm{P}$ & 18 & $(50.8)$ & & 19.5 & $(30)$ & & 112 & (336) & \\
\hline \multirow{2}{*}{ kin (batches) } & $\mathrm{N}$ & 0 & (1) & \multirow{2}{*}{0.749} & 0 & (1) & \multirow{2}{*}{0.586} & 1 & (2) & \multirow{2}{*}{0.248} \\
\hline & $\mathrm{P}$ & 0.5 & (1) & & 0 & (1) & & 1 & (3) & \\
\hline \multirow{2}{*}{ kout (batches) } & $\mathrm{N}$ & 1 & (1) & \multirow{2}{*}{0.365} & 1 & (0) & \multirow{2}{*}{0.293} & 1 & (3) & \multirow{2}{*}{0.022} \\
\hline & $\mathrm{P}$ & 1 & $(0.25)$ & & 1 & (1) & & 2 & (3) & \\
\hline
\end{tabular}


continuation

\begin{tabular}{|c|c|c|c|c|c|c|c|c|c|c|}
\hline \multirow{2}{*}{ k (batches) } & $\mathrm{N}$ & 1 & $(0)$ & \multirow{2}{*}{0.574} & 1 & (1) & \multirow{2}{*}{0.533} & 2 & (4) & \multirow{2}{*}{0.015} \\
\hline & $\mathrm{P}$ & 1 & $(1.25)$ & & 1 & $(1.75)$ & & 3 & (6) & \\
\hline \multirow{2}{*}{ kin (neighbors) } & $\mathrm{N}$ & 0 & (1) & \multirow{2}{*}{0.621} & 0 & (1) & \multirow{2}{*}{0.498} & 1 & (1) & \multirow{2}{*}{0.336} \\
\hline & $\mathrm{P}$ & 0.5 & (1) & & 0 & (1) & & 1 & (2) & \\
\hline \multirow{2}{*}{ kout (neighbors) } & $\mathrm{N}$ & 1 & (1) & \multirow{2}{*}{0.427} & 1 & $(0)$ & \multirow{2}{*}{0.406} & 1 & (2) & \multirow{2}{*}{0.011} \\
\hline & $\mathrm{P}$ & 1 & (0) & & 1 & (1) & & 1 & (2) & \\
\hline \multirow{2}{*}{ k (neighbors) } & $\mathrm{N}$ & 1 & $(0)$ & \multirow{2}{*}{0.639} & 1 & (1) & \multirow{2}{*}{0.444} & 2 & (2) & \multirow{2}{*}{0.031} \\
\hline & $\mathrm{P}$ & 1 & $(0.25)$ & & 1 & (1) & & 2 & (3) & \\
\hline \multirow{2}{*}{ betweenness } & $\mathrm{N}$ & 0 & $(0)$ & \multirow{2}{*}{0.335} & 0 & $(0)$ & \multirow{2}{*}{0.324} & 0 & $(58)$ & \multirow{2}{*}{0.510} \\
\hline & $\mathrm{P}$ & 0 & (0) & & 0 & $(49.5)$ & & 0 & $(4800)$ & \\
\hline \multirow{2}{*}{ closeness in } & $\mathrm{N}$ & $4.1 \mathrm{e}-10$ & $\left(8.2 e^{-15}\right)$ & \multirow{2}{*}{0.338} & $4.1 e^{-10}$ & $\left(3.3 e^{-14}\right)$ & \multirow{2}{*}{0.179} & $4.1 e^{-10}$ & $\left(9.8 \mathrm{e}^{-14}\right)$ & \multirow{2}{*}{0.885} \\
\hline & $\mathrm{P}$ & $4.1 e^{-10}$ & $\left(1.5 e^{-13)}\right.$ & & $4.1 e^{-10}$ & $\left(8.7 e^{-11)}\right.$ & & $4.1 \mathrm{e}^{-10}$ & $\left(9.4 e^{-14}\right)$ & \\
\hline \multirow{2}{*}{ closeness out } & $\mathrm{N}$ & $4.1 \mathrm{e}-10$ & $\left(8.2 e^{-15}\right)$ & \multirow{2}{*}{0.637} & $4.1 \mathrm{e}-10$ & $\left(5.5 \mathrm{e}^{-14}\right)$ & \multirow{2}{*}{0.589} & $4.1 \mathrm{e}-10$ & $\left(1.1 \mathrm{e}^{-13}\right)$ & \multirow{2}{*}{0.024} \\
\hline & $\mathrm{P}$ & $4.1 e^{-10}$ & $\left(4.4 e^{-13)}\right.$ & & $4.1 \mathrm{e}-10$ & $\left(3.1 \mathrm{e}^{-14}\right)$ & & $4.1 e^{-10}$ & $\left(8.3 e^{-11)}\right.$ & \\
\hline \multirow{2}{*}{ clustering in } & $\mathrm{N}$ & 0.025 & $(0.025)$ & \multirow{2}{*}{0.617} & 0 & $(0.0179)$ & \multirow{2}{*}{0.775} & 0 & $(0)$ & \multirow{2}{*}{0.394} \\
\hline & $\mathrm{P}$ & 0 & $(0)$ & & 0 & $(0)$ & & 0 & (0) & \\
\hline clustering out & $\mathrm{N}$ & 0 & $(0)$ & & 0.000572 & $(0.0449)$ & 0117 & 0 & (0) & 0.422 \\
\hline & $\mathrm{P}$ & 0 & $(0)$ & - & 0 & $(0)$ & & 0 & (0) & 0.422 \\
\hline Doropl & $\mathrm{N}$ & $8.9 \mathrm{e}-06$ & $(3.8 \mathrm{e}-06)$ & 0040 & $8.9 \mathrm{e}-06$ & $(3.0 \mathrm{e}-06)$ & 0544 & $1.1 \mathrm{e}-05$ & $(9.2 \mathrm{e}-06)$ & 0612 \\
\hline Pagekank & $\mathrm{P}$ & $9.0 \mathrm{e}-06$ & $\left(2.1 \mathrm{e}^{-06}\right)$ & 0.942 & $8.9 \mathrm{e}-06$ & $\left(4.5 e^{-06}\right)$ & 0.544 & $1.2 \mathrm{e}-05$ & $(1.0 \mathrm{e}-05)$ & 0.613 \\
\hline $\mathrm{ICC}$ & $\mathrm{N}$ & 0 & (1) & 0621 & 0 & (1) & 0556 & 1 & (3) & 0374 \\
\hline & $\mathrm{P}$ & 0.5 & (1) & 0.021 & 0 & (1) & 0.500 & 1 & (3) & 0.014 \\
\hline$\Omega r$ & $\mathrm{~N}$ & 1 & (3) & 0380 & 1 & (3) & 0060 & 2 & (6) & 00 \\
\hline C & $\mathrm{P}$ & 1.5 & (13) & 0.509 & 1 & $(3.75)$ & 0.909 & 2 & (6) & 0.09 \\
\hline
\end{tabular}

ICC, ingoing contact chain; OCC, outgoing contact chain.

Table 5. Results of the logistic regression analysis considering the herd status (positive or negative) for bovine brucellosis in the State of Mato Grosso as the outcome variable, and the base 10 logarithm of both average herd size and total degree (for animals moved) as predictor variables. The analysis considered the network for reproduction purposes.

\begin{tabular}{lccc}
\hline Variable & Odds ratio & CI $(95 \%)$ & $p$ \\
\hline $\log 10$ (herd size) & 1.41 & {$[1.01 ; 1.99]$} & 0.045 \\
$\log 10$ (degree) & 1.39 & {$[1.05 ; 1.85]$} & 0.020 \\
\hline
\end{tabular}

Within the network of bovine movements in 2007, we found a statistical association between the presence of brucellosis (in the 2003 survey) and both total degree (animals) and outdegree (for the number of animals and batches of animals sold, and the number of neighboring herds that buy animals from the herd of origin). Whatever the origin of such associations, the potential implications of this finding are important for the spread of brucellosis among herds, because it reveals that positive herds in the 2003 survey were trading (and particularly selling) more extensively in 2007 than the negative herds. This presumably increased the risk of disease spread within the state, assuming those herds 
remained positive (or infected). It is noteworthy that in the nationwide analysis for herd-level risk factors of bovine brucellosis in Brazil (MOTA et al., 2016), the risk of infection was higher for farms that purchase replacement stock from cattle traders.

The statistical differences observed in the network of movements for reproduction purposes were more significant than those observed in the other networks for the following parameters: average herd size, degree of animals, degree of batches, degree of neighbors, outdegree of neighbors, and betweenness. The purchase of animals for reproduction purposes was identified as a risk factor for bovine brucellosis in three Brazilian states (DIAS et al., 2009a; GONÇALVES et al., 2009; KLEIN-GUNNEWIEK et al., 2009). These findings also reinforce the need for diagnostic testing before permitting animal movements for reproduction purposes. Interestingly, any difference observed in betweenness was only significant between positive and negative herds within the network for reproduction purposes, suggesting that there are positive herds occupying central positions along the path of movements between other herds.

A comparison between positive and negative herds, stratified by herd size, within the network of movements for reproduction purposes, revealed statistically significant differences $(p<0.05)$ in herd size, degree, and outdegree in the category $>50$ FEM24+ only. Logistic regression analysis considering both average herd size and degree of animals as factors showed that a tenfold increase both in herd size and the number of animals traded would lead to the increased chance of a positive herd status by $41 \%(\mathrm{OR}=1.41[1.01 ; 1.99])$ and $39 \%(\mathrm{OR}=1.39[1.05 ; 1.85])$, respectively. Thus, both herd size and animal trade might contribute to the spread of brucellosis.

A statistically significant difference between positive and negative herds was noted in the total degree of batches in the network without abattoirs and the network for reproduction purposes ( $p$
$=0.017$ and $\mathrm{p}=0.006$, respectively). However, such differences were not observed in the network for fattening purposes. These findings suggest the primary influence of animal movements for reproduction purposes. The same line of reasoning applies to the difference in the total degree of animals moved between positive and negative herds.

\section{Conclusions}

Analysis of the association between herd size and the number of traded animals revealed that: the number of traded animals and the FEM24+ herd size are positively associated; the FEM24+ herd size is positively associated with the FEM24+ herd size of its neighbors within the network of cattle movement; the FEM24+ herd size of the neighbors is positively associated with the number of traded animals; and the weighted degree (animals) of the neighbors is positively associated with the degree (animals) of the herd.

Herd size was identified as a risk factor for brucellosis in the state of Mato Grosso (NEGREIROS et al., 2009). In the present study, we observed that larger herds traded animals more intensively than smaller herds $(p<0.001)$. In summary, the presence of bovine brucellosis is generally associated with larger herds. In addition, we found a presumable association between more intense trade of bovines and the presence of bovine brucellosis. Furthermore, herd size and animal trade are associated factors that might contribute to the spread of brucellosis.

On one hand, the dynamics of animal trade itself could primarily influence the spread of an infectious disease (such as brucellosis) among animals. On the other hand, as Amaku and Grisi-Filho (2015) discussed, we cannot rule out the possibility that an animal disease could affect the dynamics of the animal trade network. 


\section{Acknowledgements}

We are grateful to INDEA-MT (Instituto de Defesa Agropecuária do Estado de Mato Grosso) for providing the databases. This project was supported by FAPESP, CNPq and Capes.

\section{Appendix - Description of parameters used in the network analysis}

\section{Degree}

The degree, represented by $k$, is one of the main centrality measures of a network that can be easily calculated. The traditional definition of the degree is the number of edges connected to a particular node (CALDARELLI, 2007). In a directed graph, each node has two degrees: an in-degree $\left(k^{\text {in }}\right)$ and an out-degree $\left(k^{\text {out }}\right)$ that represent the number of edges arriving at the node and leaving it, respectively.

For an undirected graph, the degree $k_{\mathrm{i}}$ of a node $i$, is calculated by summing either the row $i$ or the column $i$ of the adjacency matrix $A(n, n)$, where $n$ is the number of nodes in the network, and can be defined as follows (CALDARELLI, 2007):

$$
k_{i}=\sum_{j=1}^{n} a_{j i}
$$

For a directed graph, the in-degree $\left(k^{i n}\right)$ and outdegree $\left(k^{o u t}\right)$ are calculated by summing the column $i$ and the row $i$, respectively, and can be defined as follows (CALDARELLI, 2007):

$$
\begin{aligned}
& k_{i}^{i n}=\sum_{j=1}^{n} a_{j i} \\
& k_{i}^{\text {out }}=\sum_{j=1}^{n} a_{i j}
\end{aligned}
$$

The total degree of a directed graph is the sum of the in-degree and out-degree (COSTA et al., 2007).

To analyze the degree on a cattle movement network, the node can be represented by specific premises (slaughterhouse, farm, etc.) and edges can be defined in three ways, resulting in three distinct classifications of degree: a. Degree weighted by animals moved: the number of cattle purchased $\left(s^{\text {in }}\right)$ and sold $\left(s^{\text {out }}\right)$ by the premises;

b. Degree weighted by batches moved: the number of batches purchased $\left(s^{\text {in }}\right)$ and sold $\left(s^{\text {out }}\right)$ by the premises;

c. Degree weighted by number of neighbors: the number of premises with which a given premises trades $\left(k^{\text {in }}\right.$ and $\left.k^{\text {out }}\right)$.

The weighted degree is also referred to as strength by some authors (COSTA et al., 2007), hence the notation $s$.

\section{Betweenness}

The betweenness of a node is given by the total geodesic distance(i.e., the shortest distances between nodes on the network) between pairs of other nodes, including the reference node (FREEMAN, 1977).

Mathematically, we define a variable $n_{s}^{i}$ for node $i$, which is equal to 1 when the geodesic between nodes $s$ and $t$ goes through $i$; and is equal to 0 , when it does not. Therefore, the betweenness is derived by the following equation (NEWMAN, 2010):

$$
B_{i}=\sum_{s t} n_{s t}^{i}
$$

\section{Closeness}

The closeness measures how close a given node is to other network nodes. According to Freeman (1979), the simplest way to calculate this measure of centrality is to define it mathematically as the inverse of the sum of the geodesic distances between the reference node and the rest of the network. Closeness has been proposed to assume higher values for those nodes that have the shortest geodesic between other network nodes. 
It is derived as follows:

$$
C_{i}=\frac{1}{\sum_{i \neq j} d_{i j}}
$$

where $C_{i}$ is the measure of closeness of node $i$ and $d_{i j}$ is the geodesic distance between nodes $i$ and $j$. If there are no geodesics between nodes $i$ and $j$, the total number of network nodes $(n)$ could be used instead of the geodesic value $(d)$ (CSARDI; NEPUSZ, 2006).

\section{Clustering Coefficient}

For undirected networks, the definition of the clustering coefficient (CC) refers to the number of triangles in the network (COHEN; HAVLIN, 2010), i.e., it is the measure of how frequently the nodes of a network are united in groups of three. According to Caldarelli (2007), the formula to calculate the clustering coefficient is as follows:

$$
C C_{i}=\frac{1}{k_{i}\left(k_{i}-1\right) / 2} \sum_{j, k} a_{i j} a_{i k} a_{j k}
$$

The CC value is high when two nodes that share a common neighbor have a high probability of being connected to each other (COHEN; HAVLIN, 2010).

It is possible to define an incoming and an outgoing clustering coefficient as follows (CALDARELLI, 2007):

$$
C C_{i}^{i n}=\frac{1}{k_{i}^{i n}\left(k_{i}^{i n}-1\right) / 2} \sum_{j, k} a_{i j} a_{k i} \frac{a_{j k}+a_{k j}}{2}
$$

and

$$
C C_{i}^{\text {out }}=\frac{1}{k_{i}^{\text {out }}\left(k_{i}^{\text {out }}-1\right) / 2} \sum_{j, k} a_{i j} a_{k i} \frac{a_{j k}+a_{k j}}{2}
$$

\section{PageRank}

PageRank is an analysis algorithm of connections in networks used by the Internet search engine Google (BRIN; PAGE, 1998). This algorithm assigns a value of the relative importance of each network node (PageRank value), considering the number of edges that a node receives (indegree) and the number of edges that its neighbors receive. In addition, it is propagated through the network, based on the premise that nodes receive important links from important nodes. PageRank is derived by (NEWMAN, 2010):

$$
x_{i}=\alpha \sum_{j} a_{i j} \frac{x_{j}}{k_{j}^{\text {out }}}+\beta
$$

where and are positive constants. In an animal movement network, the PageRank indicates the importance of the premises with regard to the number of animals bought (Figure 6).

Figure 6. Scheme of PageRank calculation for a simple network of four nodes. The nodes A, B, and C receive the same number of incoming links (i.e., one incoming link); however, node $\mathrm{C}$ has a higher PageRank than A and B, because the link that $\mathrm{C}$ receives comes from an important node (node D) that raises its PageRank.

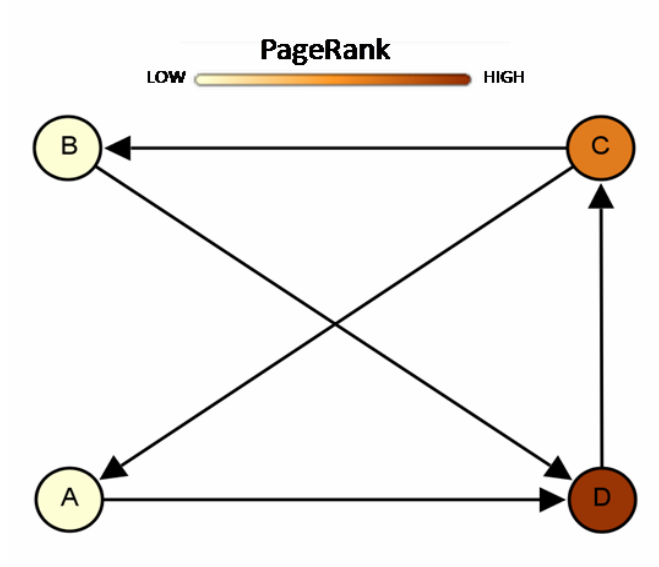




\section{References}

AMAKU, M.; GRISI-FILHO, J. H. H. The friendship paradox as a strategy for scenarios with incomplete network data. Physics of Life Reviews, Amsterdam, v. 15, p. 39-40, 2015.

AMAKU, M.; GRISI-FILHO, J. H. H.; NEGREIROS, R. L.; DIAS, R. A.; FERREIRA, F.; FERREIRA NETO, J. S.; CIPULLO, R. I.; MARQUES, F. S.; OSSADA, $\mathrm{R}$. Infectious disease surveillance in animal movement networks: an approach based on the friendship paradox. Preventive Veterinary Medicine, Amsterdam, v. 121, n. 3-4, p. 306-313, 2015.

BAJARDI, P.; BARRAT, A.; SAVINI, L.; COLIZZA, V. Optimizing surveillance for livestock disease spreading through animal movements. Journal of the Royal Society Interface, London, v. 9, n. 76, p. 2814-2825, 2012.

BIGRAS-POULIN, M.; THOMPSON, R. A.; CHRIEL, M.; MORTENSEN, S.; GREINER, M. Network analysis of Danish cattle industry trade patterns as an evaluation of risk potential for disease spread. Preventive Veterinary Medicine, Amsterdam, v. 76, n. 1-2, p. 11-39, 2006.

BRIN, S.; PAGE, L. The anatomy of a large-scale hypertextual Web search engine. Computer Networks and ISDN Systems, Amsterdam, v. 30, n. 1-7, p. 107-117, 1998.

CALDARELLI, G. Scale-free networks. Oxford: Oxford University Press, 2007. 309 p.

CHATE, S. C.; DIAS, R. A.; AMAKU, M.; FERREIRA, F.; MORAES, G. M.; COSTA NETO, A. A.; MONTEIRO, L. A. R. C.; LÔBO, J. R.; FIGUEIREDO, V. C. F.; GONÇALVES, V. S. P.; FERREIRA NETO, J. S. Situação epidemiológica da brucelose bovina no Estado do Mato Grosso do Sul. Arquivo Brasileiro de Medicina Veterinária e Zootecnia, Belo Horizonte, v. 61, p. 46-55, 2009. Suplemento 1.

CHRISTLEY, R. M.; PINCHBECK, G. L.; BOWERS, R. G.; CLANCY, D.; FRENCH, N. P.; BENNETT, R.; TURNER, J. Infection in social networks: using network analysis to identify high-risk individuals. American Journal of Epidemiology, Cary, v. 162, n. 10, p. 10241031, 2003.

COHEN, R.; HAVLIN, S. Complex networks: structure, robustness and function. Cambridge: Cambridge University Press, 2010. 238 p.

CORNER, L. A.; PFEIFFER, D.; MORRIS, R. S. Socialnetwork analysis of Mycobacterium bovis transmission among captive brushtail possums (Trichosurus vulpecula). Preventive Veterinary Medicine, Amsterdam, v. 59, n. 3, p. 147-167, 2003.
COSTA, L. F.; RODRIGUES, F. A.; TRAVIESO, G.; VILLAS BOAS, P. R. Characterization of complex networks: a survey of measurements. Advances in Physics, Abingdon, v. 56, n. 1, p. 167-242, 2007.

CSARDI, G.; NEPUSZ, T. The igraph software package for complex network research. Inter Journal, Cambridge, v. Complex Systems, 2006. p. 1695. Available at: $<$ http:// igraph.org $>$. Accessed at: 16 june 2016.

DIAS, J. A.; MÜLLER, E. E.; DIAS, R. A.; FREITAS, J. C.; AMAKU, M.; FERREIRA, F.; SILVA, M. C. P.; LÔBO, J. R.; FIGUEIREDO, V. C. F.; GONÇALVES, V. S. P.; FERREIRA NETO, J. S. Situação epidemiológica da brucelose bovina no Estado do Paraná. Arquivo Brasileiro de Medicina Veterinária e Zootecnia, Belo Horizonte, v. 61, p. 66-76, 2009a. Suplemento 1.

DIAS, R. A.; GONÇALVES, V. S. P.; FIGUEIREDO, V. C. F.; LÔBO, J. R.; LIMA, Z. M. B.; PAULIN, L. M. S.; GUNNEWIEK, M. F. K.; AMAKU, M.; FERREIRA NETO, J. S.; FERREIRA, F. Situação epidemiológica da brucelose bovina no Estado de São Paulo. Arquivo Brasileiro de Medicina Veterinária e Zootecnia, Belo Horizonte, v. 61, p. 118-125, 2009b. Suplemento 1.

FREEMAN, L. C. A set of measures of centrality based upon betweenness. Sociometry, Washington, v. 40, n. 1, p. 35-41, 1977.

Centrality in social networks conceptual clarification. Social Networks, Amsterdam, v. 1, n. 3, p. 215-239, 1979.

GONÇALVES, V. S. P.; DELPHINO, M. K. V. C.; DIAS, R. A.; FERREIRA, F.; AMAKU, M.; FERREIRA NETO, J. S.; PORTO, T. B.; ALVES, C. M.; FIGUEIREDO, V. C. F.; LÔBO, J. R. Situação epidemiológica da brucelose bovina no Estado de Minas Gerais. Arquivo Brasileiro de Medicina Veterinária e Zootecnia, Belo Horizonte, v. 61, p. 35-45, 2009. Suplemento 1.

GRISI-FILHO, J. H. H.; AMAKU, M.; FERREIRA, F.; DIAS, R. A.; FERREIRA NETO, J. S.; NEGREIROS, R. L.; OSSADA, R. Detecting livestock production zones. Preventive Veterinary Medicine, Amsterdam, v. 110, n. 3-4, p. 304-311, 2013.

INSTITUTO BRASILEIRO DE GEOGRAFIA E ESTATÍSTICA - IBGE. Pesquisa Pecuária Municipal. Rio de Janeiro: IBGE, 2015. Disponível em: $\quad<$ http://www.sidra.ibge.gov.br/bda/tabela/protabl. asp? $=73 \& \mathrm{z}=\mathrm{p} \& \mathrm{o}=29 \& \mathrm{i}=\mathrm{P}>$. Acesso em: 24 nov. 2015.

KLEIN-GUNNEWIEK, M. F. C.; AMAKU, M.; DIAS, R. A.; FERREIRA, F.; GITTI, C. B.; PEREIRA, L. A.; FIGUEIREDO, V. C. F.; LÔBO, J. R.; GONÇALVES, V. S. P.; FERREIRA NETO, J. S. Situação epidemiológica 
da brucelose bovina no Estado do Rio de Janeiro. Arquivo Brasileiro de Medicina Veterinária e Zootecnia, Belo Horizonte, v. 61, p. 77-84, 2009. Suplemento 1.

LENTZ, H. H. K.; KONSCHAKE, M.; TESKE, K.; KASPER, M.; ROTHER, B.; CARMANNS, R.; PETERSEN, B.; CONRATHS, F. J.; SELHORST, T. Trade communities and their spatial patterns in the German pork production network. Preventive Veterinary Medicine, Amsterdam, v. 98, n. 2-3, p. 176-181, 2011.

MARTÍNEZ-LÓPEZ, B.; PEREZ, A. M.; SÁNCHESVIZCAÍNO, J. M. Social network analysis. Review of general concepts and use in preventive veterinary medicine. Transboundary and Emerging Diseases, Hoboken, v. 56, n. 4, p. 109-120, 2009.

MATOPE, G.; BHEBHE, E.; MUMAC, J. B.; LUND, A.; SKJERVE, E. Herd-level factors for Brucella seropositivity in cattle reared in smallholder dairy farms of Zimbabwe. Preventive Veterinary Medicine, Amsterdam, v. 94, n. 3-4, p. 213-221, 2010.

MOTA, A. L. A. A.; FERREIRA, F.; FERREIRA NETO, J. S.; DIAS, R. A.; AMAKU, M.; GRISI-FILHO, J. H. H.; TELLES, E. O.; GONÇALVES, V. S. P. Large-scale study of herd-level risk factors for bovine brucellosis in Brazil. Acta Tropica, Amsterdam, v. 164, p. 226-232, 2016.

NEGREIROS, R. L. Caracterização e análise da rede de movimento de bovinos no Estado de Mato Grosso. 2010. Tese (Doutorado em Epidemiologia Experimental Aplicada às Zoonoses) - Faculdade de Medicina Veterinária e Zootecnia, Universidade de São Paulo, São Paulo.

NEGREIROS, R. L.; DIAS, R. A.; FERREIRA, F.; FERREIRA NETO, J. S.; GONÇALVES, V. S. P.; SILVA, M. C. P.; FIGUEIREDO, V. C. F.; LÔBO, J. R.; FREITAS, J.; AMAKU, M. Situação epidemiológica da brucelose bovina no Estado de Mato Grosso. Arquivo Brasileiro de Medicina Veterinária e Zootecnia, Belo Horizonte, v. 61, p. 56-65, 2009. Suplemento 1.
NEWMAN, M. E. J. Networks: an introduction. Oxford: Oxford University Press, 2010. 772 p.

NöREMARK, M.; WIDGREN, S. EpiContactTrace: an R-package for contact tracing during livestock disease outbreaks and for risk-based surveillance. $B M C$ Veterinary Research, London, v. 10, p. 71, 2014.

OGATA, R. A.; GONÇALVES, V. S. P.; FIGUEIREDO, V. C. F.; LÔBO, J. R.; RODRIGUES, L.; AMAKU, M.; FERREIRA, F.; FERREIRA NETO, J. S.; DIAS, R. A. Situação epidemiológica da brucelose bovina no Estado do Tocantins. Arquivo Brasileiro de Medicina Veterinária e Zootecnia, Belo Horizonte, v. 61, p. 126-134, 2009. Suplemento 1.

R CORE TEAM - R: a language and environment for statistical computing. Vienna: R Foundation for Statistical Computing, 2015. Available at: $<$ https://www.R-project. org/>. Accessed on: 16 june 2016.

SALMAN, M. D.; MEYER, M. E. Epidemiology of bovine brucellosis in the Mexicali Valley, Mexico: literature review of disease-associated factors. American Journal of Veterinary Research, Schaumburg, v. 45, n. 8 , p. 1557-1560, 1984.

SCHÄRRER, S.; WIDGREN, S.; SCHWERMER, H.; LINDBERG, A.; VIDONDO, B.; ZINSSTAG, J.; REIST, M. Evaluation of farm-level parameters derived from animal movements for use in risk-based surveillance programmes of cattle in Switzerland. BMC Veterinary Research, London, v. 11, p. 149, 2015.

SILVA, V.G. S. O.; DIAS, R.A.; FERREIRA, F.;AMAKU, M.; COSTA, E. L. S.; LÔBO, J. R.; FIGUEIREDO, V. C. F.; GONÇALVES, V. S. P.; FERREIRA NETO, J. S. Situação epidemiológica da brucelose bovina no Estado de Sergipe. Arquivo Brasileiro de Medicina Veterinária e Zootecnia, Belo Horizonte, v. 61, p. 109-117, 2009. Suplemento 1.

WEBB, C. R.; SAUTER-LOUIS, C. Investigations into the contact structure of the British sheep population. In: MEETING OF THE SOCIETY FOR VETERINARY EPIDEMIOLOGY AND PREVENTIVE MEDICINE, 20., 2002, Cambridge. Proceedings... Cambridge: SVEPM, 2002. p. 10-20. 